\title{
Review of PP2A Tumor Biology and Antitumor Effects of PP2A Inhibitor LB100 in the Nervous System
}

\author{
Jean-Paul Bryant $^{1}\left(\mathbb{D}\right.$, Adam Levy ${ }^{2} \mathbb{D}$, John Heiss ${ }^{1}(\mathbb{D})$ and Yeshavanth Kumar Banasavadi-Siddegowda ${ }^{1, *(D)}$ \\ 1 Surgical Neurology Branch, National Institute of Neurological Disorders and Stroke, National Institutes of \\ Health, Bethesda, MD 20892, USA; jxb1400@med.miami.edu (J.-P.B.); heissj@ninds.nih.gov (J.H.) \\ 2 Miller School of Medicine, University of Miami, Miami, FL 33136, USA; adam.levy@med.miami.edu \\ * Correspondence: yesh.banasavadisiddegowda@nih.gov; Tel.: +1-301-451-0970
}

Citation: Bryant, J.-P.; Levy, A.; Heiss, J.; Banasavadi-Siddegowda, Y.K. Review of PP2A Tumor Biology and Antitumor Effects of PP2A Inhibitor LB100 in the Nervous System. Cancers 2021, 13, 3087. https://doi.org/10.3390/

cancers13123087

Academic Editor: Jukka Westermarck

Received: 11 May 2021

Accepted: 18 June 2021

Published: 21 June 2021

Publisher's Note: MDPI stays neutral with regard to jurisdictional claims in published maps and institutional affiliations.

Copyright: (c) 2021 by the authors. Licensee MDPI, Basel, Switzerland. This article is an open access article distributed under the terms and conditions of the Creative Commons Attribution (CC BY) license (https:// creativecommons.org/licenses/by/ $4.0 /)$.
Simple Summary: Central and peripheral nervous system tumors represent a heterogenous group of neoplasms which often demonstrate resistance to treatment. Given that these tumors are often refractory to conventional therapy, novel pharmaceutical regimens are needed for successfully treating this pathology. One such therapeutic is the serine/threonine phosphatase inhibitor, LB100. LB100 is a water-soluble competitive protein phosphtase inhibitor that has demonstrated antitumor effects in preclinical and clinical trials. In this review, we aim to summarize current evidence demonstrating the efficacy of LB100 as an inhibitor of nervous system tumors. Furthermore, we review the involvement of the well-studied phosphatase, protein phosphatase $2 \mathrm{~A}$, in oncogenic cell signaling pathways, neurophysiology, and neurodevelopment.

Abstract: Protein phosphatase 2A (PP2A) is a ubiquitous serine/threonine phosphatase implicated in a wide variety of regulatory cellular functions. PP2A is abundant in the mammalian nervous system, and dysregulation of its cellular functions is associated with myriad neurodegenerative disorders. Additionally, PP2A has oncologic implications, recently garnering attention and emerging as a therapeutic target because of the antitumor effects of a potent PP2A inhibitor, LB100. LB100 abrogation of PP2A is believed to exert its inhibitory effects on tumor progression through cellular chemo- and radiosensitization to adjuvant agents. An updated and unifying review of PP2A biology and inhibition with LB100 as a therapeutic strategy for targeting cancers of the nervous system is needed, as other reviews have mainly covered broader applications of LB100. In this review, we discuss the role of PP2A in normal cells and tumor cells of the nervous system. Furthermore, we summarize current evidence regarding the therapeutic potential of LB100 for treating solid tumors of the nervous system.

Keywords: PP2A; LB100; nervous system; tumor biology; brain tumor; preclinical; clinical trial

\section{Introduction}

Protein phosphatase 2A (PP2A) is an evolutionarily conserved, ubiquitous serine/ threonine phosphatase that is implicated in a wide variety of regulatory cellular functions, including cell survival, DNA-damage response, tau dephosphorylation, and apoptosis [1]. PP2A is abundant in the mammalian cerebrum and is comprised of three distinct subunits: PP2A-A (structural subunit), PP2A-B (regulatory subunit), and PP2A-C (catalytic subunit) [2]. A comprehensive list of known isoforms of PP2A subunits is displayed in Table 1 [3].

Given its abundance in the central nervous system (CNS), the dysregulation of PP2A pathways can contribute to the pathogenesis of many neurodegenerative diseases [4-7]. PP2A has also received attention for its oncologic properties, suppressing tumor growth by inhibiting numerous growth and survival pathways [8,9]. Intriguingly, PP2A inhibition with the small molecule inhibitor LB100 inhibits tumor growth, opposite to the predicted effect of blocking a tumor suppressor like PP2A. 
Table 1. List of known PP2A subunits including additional associated names. Nervous system expression represents the highest level of PP2A subunit gene expression in a central nervous system structure. Genetic information was obtained from the UniProt protein sequence database (https: / / www.uniprot.org/ (accessed on 3 June 2021)).

\begin{tabular}{|c|c|c|c|}
\hline Subunit Family & Protein Isoform & Other Associated Name(s) & Nervous System Tissue Expression \\
\hline \multirow[t]{2}{*}{ A } & $\mathrm{A} \alpha$ & PR65 $\alpha$ & Anterior cingulate cortex \\
\hline & $A \beta$ & PR65 $\beta$ & Corpus callosum \\
\hline $\mathrm{B}^{\prime \prime \prime} /$ Striatin & $\mathrm{B}^{\prime \prime \prime}$ & Striatin & Corpus callosum \\
\hline \multirow{5}{*}{ B/PR55 } & $\mathrm{B} \alpha$ & $\mathrm{B} 55 \alpha / \mathrm{PR} 55 \alpha$ & Corpus callosum \\
\hline & $\mathrm{B} \beta 1$ & $\mathrm{~B} 55 \beta 1 / \mathrm{PR} 55 \beta 1$ & Corpus callosum \\
\hline & $\mathrm{B} \beta 2$ & B55 $\beta 2 /$ PR55 $\beta 2$ & Corpus callosum \\
\hline & $\mathrm{B} \gamma$ & $\mathrm{B} 55 \gamma / \mathrm{PR} 55 \gamma$ & Caudate nucleus \\
\hline & $\mathrm{B} \delta$ & B55 $\delta / P R 55 \delta$ & Dorsal/ventral thalamus \\
\hline \multirow{7}{*}{ B' / PR61 } & $\mathrm{B} \alpha$ & $\mathrm{B} 56 \alpha / \mathrm{PR} 61 \alpha$ & Corpus callosum \\
\hline & $\mathrm{B} \beta$ & B56 $\beta /$ PR61 $\beta$ & Right cerebellar hemisphere \\
\hline & $\mathrm{B}^{\prime} \gamma 1$ & B56 $\gamma 1 / \mathrm{PR} 61 \gamma 1$ & Caudate nucleus \\
\hline & $\mathrm{B}^{\prime} \gamma 2$ & B56 $2 /$ PR61 $\gamma 2$ & Caudate nucleus \\
\hline & $\mathrm{B}^{\prime} \gamma 3$ & B56 $\gamma 3 / P R 61 \gamma 3$ & Caudate nucleus \\
\hline & $\mathrm{B}^{\prime} \delta$ & B5681/PR61 & Dorsal/ventral thalamus \\
\hline & $\mathrm{B}^{\prime} \varepsilon$ & $\mathrm{B} 56 \varepsilon / \mathrm{PR} 61 \varepsilon$ & Forebrain \\
\hline \multirow{4}{*}{$\mathrm{B}^{\prime \prime} / \operatorname{Pr} 72$} & $B^{\prime \prime} \alpha$ & PR130 & Forebrain \\
\hline & $B^{\prime \prime} \alpha$ & PR72 & Forebrain \\
\hline & $\mathrm{B}^{\prime \prime} \beta$ & PR70 & Hypothalamus \\
\hline & $\mathrm{B}^{\prime \prime} \gamma$ & G5PR & C1 segment of cervical spinal cord \\
\hline \multirow{2}{*}{$\mathrm{C}$} & $\mathrm{C} \alpha$ & PP2Ac $\alpha$ & Frontal cortex \\
\hline & $C \beta$ & PP2Ac $\beta$ & Dorsal/ventral thalamus \\
\hline
\end{tabular}

LB100 abrogation of PP2A is believed to act as an adjuvant, inhibiting tumor progression by chemo- and radiosensitizing tumor cells [10]. While the implications of LB100 for many conditions have been described, an updated, detailed, and unifying review of therapeutic strategies focusing on cancers of the nervous system has not been published. Here, we discuss the role of PP2A in the context of normal nervous system processes and nervous system tumorigenesis. Furthermore, we summarize existing evidence for the therapeutic potential of LB100 in treating solid tumors of the nervous system.

\section{Role of PP2A in Cellular Signaling Pathways}

Cell cycle initiation and apoptosis are regulated by an array of intricate signaling pathways. The normal functioning of key regulatory elements within these pathways is essential for maintaining physiologic cellular behavior, with aberrant expression often leading to significant cellular pathology. We review here the most critical pathways with known associations with PP2A.

\subsection{Mechanistic Target of Rapamycin (mTOR)}

The mTOR signaling pathway has been extensively studied because of its involvement in many diverse cellular processes and its oncologic implications. The mTOR pathway accumulates the necessary elements for continued cell division and is stimulated by amino acids, the products of cellular metabolism, and growth factors [11]. This pathway promotes anabolic processes including lipid synthesis and ribosome biogenesis while inhibiting catabolic processes such as autophagy [11]. Ribosomal S6 kinase (S6K) and the eIF4E 
binding protein 1 (4E-BP1) are the most well-characterized substrates of mTOR [12]. At low levels of mTOR activity, 4E-BP1 remains hypophosphorylated, promotes binding with eIF4E, and blocks translation initiation. Conversely, high mTOR activity leads to ample phosphorylation of 4E-BP1, the subsequent release of eIF4E, and the initiation of cap-dependent translation [13].

Signaling molecules activated upstream and downstream of mTOR are implicated in oncogenesis [14]. Receptor tyrosine kinases (RTKs) activate phosphatidylinositol 3-kinase (PI3K) and initiate a signaling cascade leading to the mTORC1 and mTORC2 complexes [14]. Genetic alterations or amplifications are the usual causes of the constitutive activation of upstream protein molecules leading to aberrant signal transduction through mTOR complexes. EGFR gene mutations activating mTOR have been studied in colorectal cancers, glioblastomas (GBM), and non-small-cell lung cancer (among others) [12].

Downstream effectors of the mTOR signaling pathway play a critical role in oncogenesis by regulating cancer cell survival, growth, and biomolecule synthesis. Nakamura et al. discovered that $\mathrm{S6K} 1$ is a mediator of glial cell transformation and that its knockdown reduced intracranial tumor size [15]. 4EBP-1 is thought to be an important molecular marker of cancer cell malignancy, and its expression correlated with poorer prognosis in a variety of human malignancies [16].

PP2A interacts with mTOR and other effectors in the mTOR signaling pathway (Figure 1) [14]. For example, Peterson et al. showed that FKBP12-rapamycin-associated protein inhibits the PP2A-mediated dephosphorylation of mTOR effectors 4EBP-1 and S6K (Figure 1) [17]. They also found that mTOR can inactivate PP2A and activate S6K. This activation induces ribosomal biogenesis and cell growth. PP2A was also reported to affect upstream members and regulatory elements of the PI3K/Akt/mTOR pathway [18]. TIPRL, an mTOR regulator, was shown to associate with the catalytic subunit of PP2A (PP2AC) to stimulate mTOR, and this complex was required for TIPRL-dependent mTORC1 signaling [18].

The mTOR pathway has been implicated in nervous system tumorigenesis in inherited brain tumor predisposition syndromes and glioma [19]. Mutations in the gene of mTOR pathway protein PTEN predispose individuals to PTEN hereditary hamartoma tumor syndromes [20]. Those harboring these mutations are at greater risk of developing thyroid and breast cancer and, to a lesser extent, cerebellar dysplastic gangliocytomas, meningioma, and intracranial vascular malformations [20]. Glioma development is also associated with mTOR hyperactivation. EGFR gene amplification, often found in GBM, activates PI3K in nearly half of cases [21]. Furthermore, about $40 \%$ of patients with GBM have deleterious PTEN gene tumor mutations [22]. 


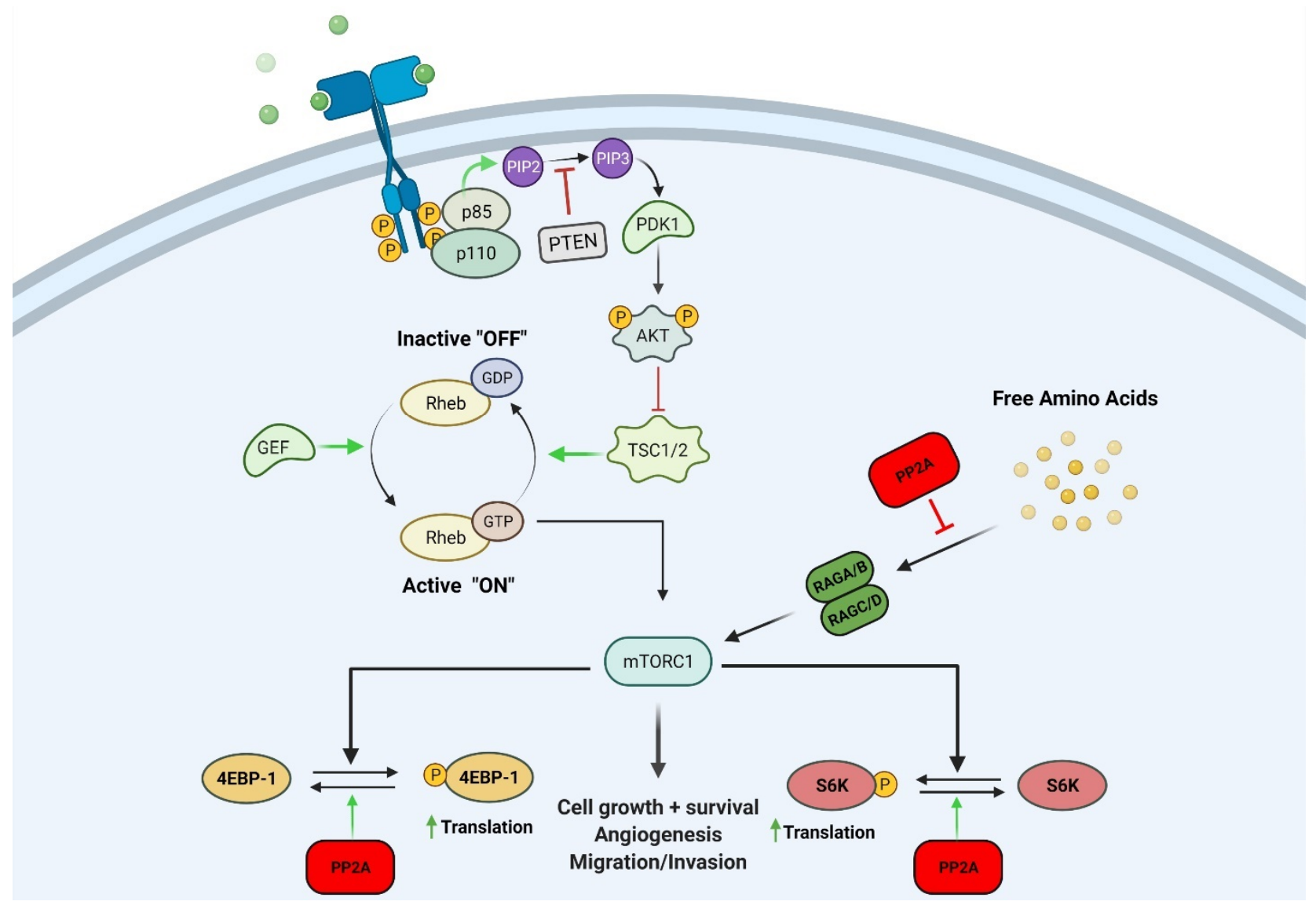

Figure 1. Schematic representation showing the mechanism in which PP2A can negatively regulate the mTOR pathway. PP2A can inhibit mTOR effectors 4EBP-1 and S6K by reversing their phosphorylation state. PP2A can also inhibit nutrient signaling to RAG complex proteins thereby inhibiting the mTOR pathway. Figure created with BioRender.com.

\subsection{Wnt Signaling Pathway}

Wnt signaling is a fundamental and essential pathway for embryonic development and normal postdevelopment homeostasis. Its primary function is to activate cell division promoters and regulate the proper initiation of the cell cycle [23]. Wnt signaling is activated by Wnt binding to the frizzled receptor, forming an intracellular complex that prevents degradation of the regulatory protein $\beta$-Catenin [24]. Free and intact $\beta$-Catenin can then bind to transcription factors that activate Wnt response genes (such as cyclin D1 and $\mathrm{c}-\mathrm{Myc}$ ) that promote cell division [25]. The absence of Wnt bound to its receptor allows $\beta$-Catenin to be degraded by a complex comprised of adenomatous polyposis coli (APC), axin, glycogen synthase $3 \beta$ (GSK3 $\beta$ ), and CK1 [23]. Wnt has been extensively studied in relation to its implications in human cancer because of its essential role in inducing embryonic cellular characteristics [26-28].

$\beta$-Catenin is the primary effector of the Wnt pathway, and its function is contingent on the phosphorylation state of its residues. Phosphorylation at the S37 and S33 residues facilitates the binding of $\beta$-transducin, a ubiquitin ligase, which targets the $\beta$-Catenin protein for degradation [29]. When phosphorylated, other members of the pathway, such as APC and axin, have increased affinity for $\beta$-Catenin and promote its degradation [30,31]. Phosphorylation of Wnt pathway proteins can be modified by protein phosphatases, including PP1 and PP2A [32,33]. PP2A can exert activating and inhibitory effects on the Wnt pathway. Positive regulation of Wnt signaling is largely attributable to a PP2A-B family regulatory subunit, PR55 $\alpha$ [34,35]. PR55 $\alpha$ has been shown to mediate PP2A-dependent dephosphorylation of $\beta$-Catenin [34]. In a study by Zhang et al., PR55 $\alpha$ depletion resulted in $\beta$-Catenin degradation, suggesting that PR55 $\alpha$ may positively regulate Wnt pathway 
signaling [34]. Interestingly, PP2A also demonstrated inhibitory effects on the Wnt signaling pathway. PP2A-mediated negative regulation of the Wnt signaling pathway occurs through proteins other than $\beta$-Catenin. For example, treatment with the PP2A inhibitor okadaic acid in mouse embryonic teratocarcinoma cells was reported to enhance Wnt signaling [36]. Furthermore, PP2A can dephosphorylate GSK3 $\beta$ and facilitate its kinase activity, resulting in phosphorylation and subsequent ubiquitination of $\beta$-Catenin (Figure 2) [37].

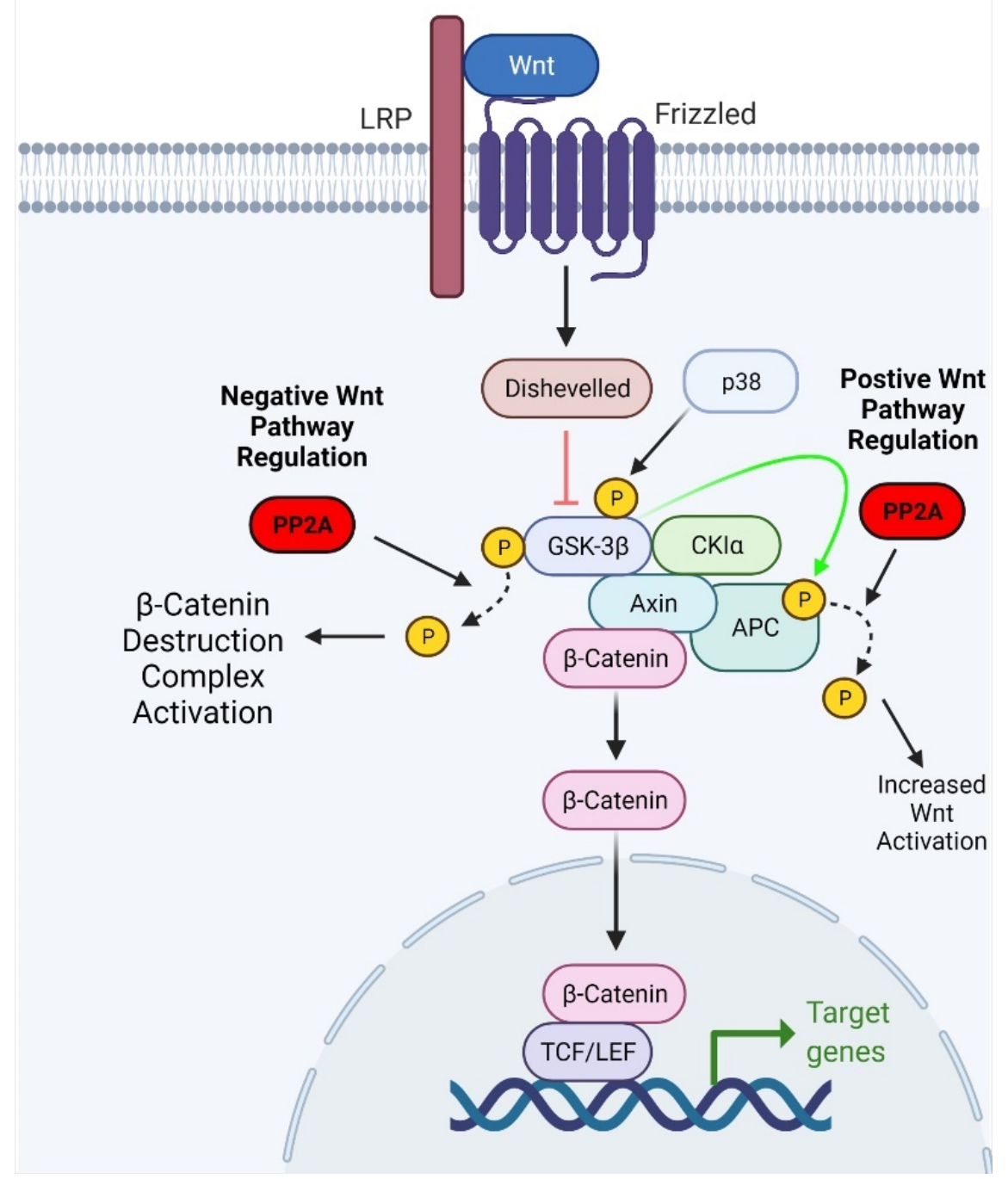

Figure 2. Schematic representation of the effect of PP2A on Wnt signaling. PP2A can reverse p38dependent phosphorylation of GSK3 $\beta$, thus activating its kinase activity. Activation of GSK3 $\beta$ leads to the ubiquitination and degradation of $\beta$-Catenin. Adapted from "Wnt Beta-Catenin Signaling Pathway," by BioRender.com (2021). Retrieved from https:/ / app.biorender.com/biorender-templates, accessed on 11 May 2021.

The upregulation of Wnt signaling has been implicated in GBM development because of its role in embryonic brain development and stem cell maintenance. Canonical Wnt signaling positively regulates transcription factor LEF1, which promotes cell migration and invasiveness in GBM and other cancers [38]. The Wnt pathway is critical to the maintenance of GBM stem cell properties. Furthermore, patients with GBM and aberrant signaling in the canonical Wnt pathway have a worse prognosis, and their tumors are more resistant to chemo- and radiotherapy [39,40]. Lastly, Wnt receptor Frizzled 4 is upregulated in invasive GBM cells and promotes the expression of epithelial to mesenchymal transition regulator SNAI1 [41]. 


\subsection{Mitogen-Activated Protein Kinase (MAPK) Signaling Pathway}

MAPKs mediate intracellular signaling and a wide variety of cellular processes, including differentiation, proliferation, and apoptosis [42,43]. This signaling pathway is comprised of four discrete cascades: the extracellular signal-related kinases (ERK1/2), Jun amino-terminal kinases (JNK1/2/3), p38-MAPK, and ERK5 [43]. This pathway is activated by upstream kinases (MAPKK kinases) which are stimulated by stress signals, cytokines, and growth signals [3]. The ERK1/2 pathway was the first cascade discovered and consequently is the best studied. It is a prominent promoter of cellular proliferation, survival, and transformation and therefore plays an important role in tumorigenesis [44]. Increased ERK expression occurs in many human malignancies, including breast cancer, colorectal cancer, and ovarian cancer (among others) [45].

While PP2A can positively regulate ERK/MAPK signaling, its main effect is to downregulate the ERK/MAPK pathway. Ugi et al. found that PP2A can bind to SHC, a Ras activator, and negatively regulate Ras stimulation [46]. Other studies have since supported the notion that PP2A downregulates the ERK/MAPK pathway through modifying various effectors. Lao et al. found that PP2A can dephosphorylate sprouty2, ultimately disrupting the activation of Ras and downregulating fibroblast growth factor (FGF)-mediated ERK/MAPK activation (Figure 3) [47].

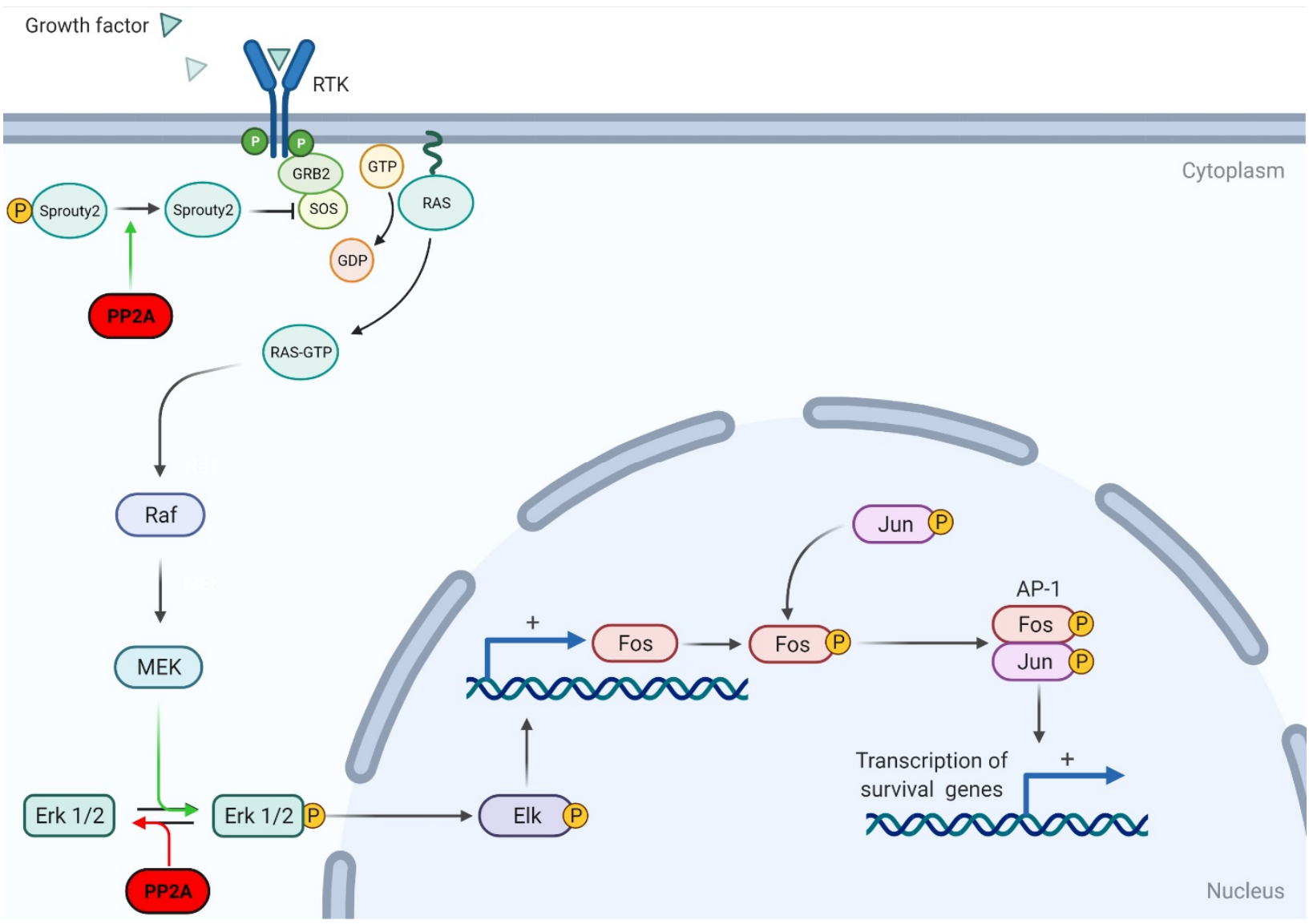

Figure 3. Schematic representation of PP2A regulation on the MAPK pathway. PP2A can dephosphorylate Sprouty2, thus inhibiting RTK-dependent activation of the MAPK/Erk pathway. PP2A can also dephosphorylate Erk1/2, preventing the activation of downstream effector Elk and preventing the transcription of transcription factors Fos and Jun. Adapted from "Ras Activation," by BioRender.com (2021). Retrieved from https:/ /app.biorender.com/biorender-templates, accessed on 11 May 2021.

Although the role of PP2A as a negative regulator of the ERK/MAPK pathway is well documented, there is also opposing evidence indicating that PP2A can positively 
regulate ERK signaling. Studies showed that the binding of PP2A regulatory subunit PR130 to SH2 domain-containing inositol 5-phosphatase 2 (known as SHIP2) is required for SHIP2-mediated stabilization of the EGFR [48]. Furthermore, Jaumot and Hancock demonstrated that PP1 and PP2A positively regulate the ERK/MAPK pathway by contributing to Raf-1 activation via dephosphorylation of its S259 residue [49]. In their in vitro experiments, the administration of PP2A inhibitors significantly inhibited Raf-1 activation. The opposing actions of PP2A on MAPK signaling are complex and further attention is needed to elucidate the net effect of PP2A on MAPK signaling.

MAPK pathway activation and deregulation are involved in brain tumor development and other nervous system pathologies. The product of the NF1 gene, neurofibromin, acts as a GTPase-activating protein for MAPK pathway protein Ras [50]. Germline mutations in the NF1 gene cause Neurofibromatosis type 1 (NF1). Mutation or deletion of the second copy of the NF1 gene within the cell results in the loss of neurofibromin, increased Ras activation, and tumorigenesis [50]. Approximately 15\% of patients with NF1 develop gliomas, mainly pilocytic astrocytomas, often occurring in the optic pathway [51]. The MAPK pathway plays a key role in the development of GBM by activating cell proliferation and transcription factor CREB, which regulates cyclin D-1 in GBM cells [52]. Furthermore, studies have shown that inhibiting the MAPK pathway inhibits the proliferation of GBM cells [53].

\section{Role of PP2A in Neurodevelopment and Neurophysiology}

The PP2A family of Ser/Thr phosphatases affects cellular pathways that are essential for a variety of neural processes, including neurodevelopment, stem-cell regeneration, neurotransmitter release, and postsynaptic responses. Over the past two decades, several knockout mouse models have highlighted the importance of PP2A in neural development. Liu et al. demonstrated that the cerebral knockout of the protein phosphatase 2AC $\alpha$ (PP2A$\mathrm{C} \alpha$ ) gene via the Cre-loxP targeting system resulted in cerebral cortical atrophy, marked neuronal shrinkage, synaptic plasticity impairments, and learning deficits [54]. Results suggested that PP2AC $\alpha$ downregulated the Hippo cascade in neural progenitor cells (NPCs) that is essential for normal neuronal growth and protein synthesis. Knockout of the PP2A-C $\alpha$ gene also activated tumor suppressor p73 which in turn suppressed GLS2 activity and ultimately the glutamate-glutamine cycle, depriving NPCs of sufficient glutamine for protein synthesis. In a separate study, Yamashita et al. illustrated that PP2A-C and its regulatory protein $\alpha 4$ regulated hippocampal protein calmodulin kinase II $\alpha$ (CAMKII $\alpha)$, a kinase involved in memory, spatial learning, and long-term potentiation (LTP) $[55,56]$. In this study, a knockout mouse model inhibiting the expression of CNS $\alpha 4$ (NO- $\alpha 4 \mathrm{KO}$ ) was prepared via conditional targeting. NO- $\alpha 4 \mathrm{KO}$ mice exhibited greater latency in both spatial and avoidance learning. Reducing PP2A activity increased hippocampal CAMKII $\alpha$ activity in NO- $\alpha 4 \mathrm{KO}$ mice, providing evidence that PP2A/ $\alpha 4$ suppresses CAMKII $\alpha$ support of LTP and memory.

PP2A has been shown to regulate several other neurodevelopmental proteins, including GSK-3 $\beta$, Dock6, tau, and collapsing response mediator protein II (CRMPII) [57-60]. PP2A also appears to be critically involved in axon morphogenesis. Miyamoto et al. showed that PP2A, in conjunction with protein kinase B (Akt), is responsible for Dock6-mediated axon extension and branching of dorsal root ganglion neurons [58]. A series of in vitro immunoassays of hippocampal rat neurons showed that PP2A complexes with Dock6 during initial axon development. Similarly, Zhu et al. identified the relationship between PP2A and CRMPII in axonal elongation [59]. PP2A was observed to dephosphorylate CRMPII at its Thr514 residue, activating the protein and enabling normal microtubule formation, actin reorganization, and axon protein shuttling in developing neurons.

The PP2A family of phosphatases has also been documented to modulate neurotransmitter release and postsynaptic responses [61]. Sim et al. first identified PP2A's involvement in the neurosynaptic release of glutamate, aspartate, and GABA [61]. They found that the inhibition of PP2A via low molar okadaic acid in isolated rat synaptosomes increased the 
release of the aforementioned neurotransmitters by 34-89\%. Later Beaulieu et al. identified PP2A as a regulator of Akt-mediated D2 class-receptor activity [62]. Using a functional and in vivo mouse model, PP2A was shown to contribute to an Akt/ $\beta$-arrestin 2/PP2A scaffolding complex. This complex was determined to be a component of an alternative pathway for D2 receptor expression involved in dopamine-associated behaviors.

Among the proteins PP2A interacts with, perhaps the most extensively studied is tau. Tau is an axonal microtubule-associated protein shown to regulate microtubule dynamics, axonal transport, and signaling [63]. Tau has six isoforms and $37 \mathrm{Ser} / \mathrm{Thr}$ phosphorylation sites [64]. PP2A dephosphorylates the Ser/Thr tau sites, and accounts for $71 \%$ of all tau phosphatase activity in the brain, warranting its extensive study [65]. Sontag et al. first observed that PP2A/B $\alpha$ binds directly to tau and dephosphorylates it [66]. A series of in vitro models using human NT2 neuronal precursor cells showed the direct interaction of PP2A/B $\alpha$ and tau and that tau was hyperphosphorylated in the absence of PP2A/B $\alpha$. Schild et al. later demonstrated similar results in vivo: tau phosphorylation increased significantly when PP2A/B $\alpha$ was downregulated [67].

Tau's most recognized role in normal physiology is to regulate microtubular dynamics. Neurons affected by the aberrant hyperphosphorylation of tau cannot assemble microtubules, leading to axonal transport deficits and tau aggregations that manifest in a family of neurodegenerative diseases known as tauopathies [68]. As PP2A inhibition contributes to the hyperphosphorylation of tau, PP2A dysfunction can contribute to the pathogenesis and severity of several tauopathies, including Alzheimer's Disease (AD), progressive supranuclear palsy (PSP), and Parkinsonism-dementia complex (PDC) $[4,6,69,70]$. PP2A prevents hyperphosphorylation of tau via the downregulation of several CNS Ser/Thr kinases involved in the pathogenesis of AD, including GSK-3 $\beta$, JNK, and extracellularregulated kinase (ERK) [71]. Sontag et al. observed dramatically decreased PP2A/B $\alpha$ in brain areas affected by AD [6]. Furthermore, reduced levels of PP2A/B $\alpha$ were inversely proportional to neurofibrillary tangle load in AD-affected neurons. Later, Park et al. demonstrated that PP2A contributed to the accumulation of hyperphosphorylated tau and the resulting neurodegeneration observed in tauopathies [69].

PP2A inactivation in cancer can be mediated by several processes, including somatic mutation, suppression of subunits, and upregulation of endogenous inhibitors [72-77]. As it is a master cellular regulator, PP2A activation has been identified as a strategy for tumor suppression in several oncological therapies [78].

Converse to PP2A's homeostatic regulatory functions mentioned above, the isoforms PR72 and PR130 of the B" family of PP2A have been identified as tumor promoters, supporting prosurvival signaling and metastasis $[48,79]$. Recently, Tang et al. detailed the role of PP2A in regulating the Hippo-YAP signaling pathway in gastric cancer [80]. Dysregulation and subsequent loss of the tumor suppressor activity exhibited by Hippo has been indicated in a variety of cancers. Under normal conditions (Hippo turned on), Hippo kinases MST 1/2 phosphorylate LATS1 and LATS2 kinases, which then phosphorylate YAP and TAZ, causing the cytoplasmic sequestration of these proteins [81]. When the Hippo pathway is turned off, YAP and TAZ translocate to the nucleus and affect target gene transcription [82]. The dysregulation of this pathway has been implicated in cellular hyperproliferation and tumorigenesis [80]. Tang and colleagues demonstrated that PP2A-B subunit B"' (striatin family of proteins), specifically Striatin 3, recruits MST1/2, promoting its dephosphorylation and activating YAP [80]. Consequently, Striatin 3 upregulation has resulted in a poor prognosis in gastric cancer patients [80]. This highlights the role of PP2A as a potential oncogene, elucidating the importance of LB100 as a PP2A inhibitor. Janssens et al. identified that PR130 increased malignant cell migration and decreased cell-substratum adhesion when complexed with LIM protein lipoma-preferred partner (LPP) [79]. The loss of PR130 expression in HT1080 fibrosarcoma cells resulted in increased cellular adhesion to collagen while simultaneously decreasing cell migration in wound healing and transwell migration assays. In a separate study, Zwaenepoel et al. showed that PR130 prevented epidermal growth factor (EGF) receptor degradation, which resulted 
in sustained EGF-mediated signaling, driving the cellular proliferation, metastasis, and angiogenesis characteristics of many cancers [48].

In regard to a potential mechanism by which LB100 could be sensitive to DNAdamaging therapies, the loss of B55 $\alpha$ function was observed in up to $40 \%$ of lung carcinomas. Kalev et al. observed that inhibition of $B 55 \alpha$ impaired homologous recombination (HR) DNA repair by inhibiting ATM and inducing $G_{1}-S$ phase cell cycle arrest [83]. Anticancer therapies were devised to radiosensitize cancer cells by inhibiting the B55 $\alpha$ subunit of PP2A and preventing homologous recombination (HR) repair of radiation-induced DNA damage in tumor cells. Wei et al. confirmed that PP2A/A $\alpha$ inhibition radiosensitized pancreatic cancer cells via the inhibition of HRR and hastened cell death following treatment [84]. In summary, PP2A serves as a potential target in cancer therapy given its positive regulatory roles in several signaling pathways that can bolster tumorigenesis and malignant disease characteristics.

\section{LB100 as Therapy for Solid Nervous System Tumors}

LB100 is derived from the synthetic anticancer compound and PP2A inhibitor norcantharidin, a homolog of the naturally occurring cantharidin used in traditional Chinese medicine $[85,86]$. It is a water-soluble small molecule that competitively inhibits PP2A by directly binding to PP2A-C and reducing its catalytic activity [87]. While improvements have been made to increase the specificity of protein phosphatase inhibitors, naturally occurring compounds, including cantharidin, only demonstrated relative specificity to PP2A and homologous serine/threonine phosphatases [88]. PP1, PP2B, PP4, PP5, PP6, and PP7 are among these homologs which share an extensive similarity in their catalytic centers to PP2A-C $[88,89]$. This highlights the importance of understanding the bioactivity of LB100 as an inhibitor of abundant protein phosphatases other than PP2A. Further studies are likely warranted to elucidate the inhibitory potential of LB100 among phosphatases that have tumor suppressor or oncogenic functions.

For example, PP5 has been shown to be overexpressed in a variety of mammalian cancers, including glioma and osteosarcoma [90-92]. Therefore, inhibition of the catalytic activity of PP5 could have therapeutic potential. Interestingly, LB100 has recently emerged as a potential inhibitor of PP5. In addition to binding to PP2A-C, LB100 can bind to and inhibit PP5C [93]. PP2A-C and PP5C share a common catalytic mechanism, evidenced by the significant structural homology of these enzymes' catalytic pockets [93]. Initial preclinical and clinical studies have shown that LB100 is efficacious in targeting tumors of the nervous system, entering the tumor through the permeable blood-tumor barrier. Another direct inhibitor of PP2A, LB102, is a lipid-soluble homolog of LB100 that has antitumor efficacy demonstrated by the chemosensitizing of GBM cells to DNA-alkylating agents [10,94]. LB100 and LB102 inhibit PP2A similarly, but LB102 has greater lipid solubility, affording it greater blood-brain barrier penetrance and higher drug levels in brain tissue surrounding the main tumor mass [10].

\subsection{Glioblastoma}

Glioblastoma is the most common primary malignant brain tumor and is highly aggressive. Despite research revealing its genetics, epigenetics, and molecular pathogenesis, therapeutic advances have been limited and its prognosis remains dismal. On average, patients survive 12-15 months after GBM diagnosis. GBM survival is prolonged somewhat by surgery, radio-, and chemotherapy, but these measures cannot stop the disease progression, which is thought to arise from the ability of subsets of tumor stem cells to self-renew and resist chemotherapeutic agents. A better understanding of the mechanisms by which tumor stem cells evade chemo- and radiotherapy may elucidate molecular pathways that can be targeted to prevent tumor stem cell chemo- and radioresistance. One such investigation was conducted by Lu et al. who studied the effect of LB100 on the nuclear receptor corepressor (N-CoR) pathway (Table 2) [95]. This pathway has a putative role in preserving the immortal nature of undifferentiated tumor stem cells and 
is overexpressed in GBM [96]. Inhibition of PP2A with LB100 led to decreased expression of N-CoR, increased levels of phosphorylated Akt kinase, and decreased tumor cell proliferation in U87 and U251 malignant glioma cell lines [95]. In vivo experiments in mice with U87 glioma xenografts demonstrated that systemic treatment with LB100 reduced mean tumor volume by $73 \%(p<0.001)$ compared to controls [95]. The same group followed up these studies by investigating the effects of PP2A inhibition with LB100 on U251 GBM cells in vivo and in vitro following radiation treatment [97]. They reported that LB100 administration sensitized GBM cells to the cytotoxic effects of radiation in vitro and significantly delayed tumor growth in vivo after radiation $(p<0.001)$ [97]. Recently, another study reported combining LB100 and chimeric antigen receptor (CAR)-engineered $\mathrm{T}$ cells to treat GBM (Table 2) [98]. Cui et al. initially tested the combination of CARengineered $\mathrm{T}$ cells targeting carbonic anhydrase IX (CAIX), a protein involved in hypoxic signaling, and LB100 in GBM cell lines [98]. Combination therapy in vitro demonstrated a synergistic effect of LB100 and CAR-T cells and a significant increase in cytotoxic markers. Later, in vivo experiments in the U251-Luc glioma mouse model showed that combination therapy significantly increased tumor-infiltrating lymphocytes (TILs) in harvested tumors $(p<0.05)$ and overall survival. This suggested that LB100 was effective in reducing the tumor burden in GBM and could also synergize with immunotherapeutics. Maggio et al. investigated therapy for GBM using LB100 combined with immune checkpoint inhibitor PD1 (Table 2) [99]. They implanted mice with glioma cell lines, administered the combination therapy, and assessed overall survival and tumoral penetration of TILs. LB100 and PD1 blockade combination therapy significantly increased survival compared to monotherapy alone $(p<0.05)$. Furthermore, tumors regressed completely in $25 \%$ of mice in the combination treatment group, whereas this was not the case for any of the mice in the monotherapy treatment groups or vehicle-only controls. Flow cytometry performed on the tumor-harvested TILs demonstrated a significant increase in CD8+ T-cells in the combination therapy group compared to controls, LB100 monotherapy cohort, and PD1 blockade alone cohort $(p<0.0005, p<0.005$, and $p<0.05$, respectively) [99]. Most recently, our group studied the effects of combining LB100 with the knockdown of protein arginine methyltransferase 5 (PRMT5). For these experiments, patient-derived primary glioblastoma neurospheres (GBMNS) were initially transfected with PRMT5 siRNA (Table 2) [100]. LB100 administration in conjunction with PRMT5 knockdown was then studied in the in vitro and in vivo intracranial mice xenografts models. We found that LB100 significantly reduced the viability of PRMT5-depleted GBMNS by inducing necroptosis. In vivo studies showed that combination therapy significantly decreased tumor volume and prolonged the survival of mice compared to the PRMT5 knockdown and control groups. LB100 alone did not increase the survival of GBMNS implanted mice. Overall, LB100 may increase the therapeutic effects of other available therapeutic agents against GBM.

\subsection{Pheochromocytoma}

While LB100 has been better studied for GBM therapy, it has also been explored as a chemotherapeutic adjunct in other central and peripheral nervous system tumors. One such example is the treatment of the highly drug-resistant neuroendocrine tumor, pheochromocytoma. Pheochromocytomas are slow growing, and their low growth fraction contributes to their high resistance to chemo- and radiotherapy [101]. While most pheochromocytomas and paragangliomas are benign, reports estimate that $11-31 \%$ of patients present with or develop metastatic disease [102]. Martiniova et al. explored whether combining LB100 with the monofunctioning alkylating prodrug Temozolomide (TMZ) could improve TMZ's effectiveness, applying this combination therapy on a pheochromocytoma cell line and in an in vivo mouse model (Table 2) [101]. TMZ alkylates single stranded DNA at specific locations to produce O6-methylguanine nucleotides, which results in thymine insertion instead of correctly inserting cytosine. This results in the formation of single and double stranded DNA breaks leading to G2/M cell cycle arrest and, subsequently, tumor cell apoptosis [103]. 
The LB100 and TMZ combination therapy studied in vitro modestly reduced pheochromocytoma cell proliferation. In the in vivo model, mice developed metastatic tumors. Combination therapy resulted in complete tumor remission in $40 \%$ of these mice and significantly delayed hepatic tumor growth in the remainder [101]. Histological sectioning of treated liver pheochromocytoma revealed extensive tumor necrosis. The in vivo tumor remissions and delay in hepatic tumor growth in this initial study of the effect of LB100 combination therapy on pheochromocytomas suggest that LB100 deserves further investigation as an adjunct to TMZ in treating metastatic pheochromocytoma.

\subsection{Medulloblastoma}

Medulloblastoma $(\mathrm{MB})$ is the most common primary malignant brain tumor in the pediatric population, accounting for nearly $20 \%$ of all CNS tumors in children [104,105]. The standard treatment regimen for these tumors involves maximal gross total resection followed by radiotherapy and chemotherapy [106]. Some molecular and histological variations of MBs have favorable prognoses, but patients with group 3 and/or recurrent tumors have poor overall survival [107]. Treatment options for patients with recurrent tumors are limited because these neoplasms are often resistant to chemotherapy and radiation, and novel therapeutic approaches are sorely needed. Ho et al. studied the effect of LB100 and the alkylating platinum analog cisplatin on $\mathrm{MB}$ cells in vitro and in vivo in an intracranial xenograft mouse model (Table 2) [87]. Cisplatin induces DNA crosslinks which prevents repair, blocks cell division, and causes apoptotic cell death [108]. In vitro, LB100 monotherapy increased apoptosis in a dose-dependent manner in two MB cell lines and also induced G2/M cell cycle arrest. LB100 monotherapy significantly decreased MB cell migration compared to cisplatin monotherapy and untreated control cells $(p<0.05)$. Combination therapy with LB100 and cisplatin significantly increased the number of apoptotic tumor cells compared to controls $(p<0.05)$. In vivo experiments confirmed the therapeutic efficacy of the LB100 and cisplatin combination observed in MB cell lines. Combination therapy reduced tumor growth, measured 64 days after implantation, significantly more than cisplatin therapy alone $(p<0.05)$. The potent in vivo antineoplastic activity of the LB100 and cisplatin combination warrants further investigation.

\subsection{Diffuse Intrinsic Pontine Glioma}

Diffuse intrinsic pontine glioma (DIPG) is the most common pediatric brainstem tumor and has a uniformly fatal prognosis [109]. Radiation therapy is the only treatment with some efficacy against DIPG, extending average survival only by a few months. The discovery and development of novel therapeutics for this devastating childhood cancer is paramount. To identify DIPG susceptibilities, Schramm et al. used a pooled short hairpin RNA library, next-generation sequencing, and a large-scale gene knockdown approach (Table 2) [110]. These investigators identified fibroblast growth factor receptor signaling and PP2A as the top depleted hits and important potential targets for inhibition [110]. They found in two DIPG cell lines that LB100 treatment for $2.5 \mathrm{~h}$ induced phosphorylation of Akt and cell cycle regulator PLK1 and that LB100 treatment for $50 \mathrm{~h}$ induced apoptosis in a dose-dependent manner. The involvement of PP2A in the regulation of apoptotic and proliferative signaling pathways in DIPG tumor samples suggests that PP2A targeting should be explored further as a primary and adjunctive therapeutic agent for DIPG. 
Table 2. Overview of reviewed studies involving the use of LB100 as monotherapy or combination therapy against tumors of the nervous system. CAIX = Carbonic Anhydrase IX; CAR = Chimeric Antigen Receptor; DIPG = Diffuse Intrinsic Pontine Glioma; FGFR = Fibroblast Growth Factor Receptor; GBM = Glioblastoma; NB = Neuroblastoma; NCoR = Nuclear Receptor Corepressor 1; PHEO = Pheochromocytoma; POD = Postoperative Day; PRMT5 = Protein arginine methyltransferase 5.

\begin{tabular}{|c|c|c|c|}
\hline $\begin{array}{l}\text { Investigators } \\
\text { (Year) }\end{array}$ & Tumor Type & $\begin{array}{l}\text { Treatment } \\
\text { Method }\end{array}$ & Outcome \\
\hline Lu et al. [95] (2010) & Glioblastoma & LB100 only & $\begin{array}{l}\text { LB100 inhibited PP2A and caused dose-dependent } \\
\text { antiproliferative activity in two GBM cell lines. LB100 treatment } \\
\text { resulted in a significant reduction in tumor volume compared to } \\
\text { controls }(p<0.001) \text { in vivo. In vivo experiments also resulted in } \\
\text { decreased nuclear N-CoR expression. }\end{array}$ \\
\hline $\begin{array}{l}\text { Gordon et al. [97] } \\
\qquad(2015)\end{array}$ & Glioblastoma & $\begin{array}{l}\mathrm{LB} 100 \text { and } \\
\text { radiation therapy }\end{array}$ & $\begin{array}{l}\text { LB100 resulted in radiation dose enhancement and increased } \\
\text { mitotic catastrophe. Combination therapy significantly enhanced } \\
\text { tumor growth delay while decreasing p53 in vivo. Combination } \\
\text { therapy also increased the overall survival of mouse xenografts. }\end{array}$ \\
\hline $\begin{array}{l}\text { Cui et al. [98] } \\
\text { (2020) }\end{array}$ & Glioblastoma & $\begin{array}{l}\text { LB100 and CAR-T } \\
\text { cells }\end{array}$ & $\begin{array}{l}\text { Anti-CAIX CAR-T cell and LB100 combination therapy resulted } \\
\text { in significant cytotoxicity against GBM tumor cells and increased } \\
\text { cytokine production compared to control T-cell treatment in vitro. } \\
\text { Combination therapy significantly increased tumor regression } \\
\text { compared to monotherapy in vivo }(p<0.05) \text { and significantly } \\
\text { prolonged survival }(p<0.001) \text {. }\end{array}$ \\
\hline $\begin{array}{l}\text { Maggio et al. [99] } \\
\qquad(2020)\end{array}$ & Glioblastoma & $\begin{array}{l}\text { LB100 and PD-1 } \\
\text { inhibition }\end{array}$ & $\begin{array}{c}\text { Combination therapy significantly improved survival compared } \\
\text { to monotherapy }(p<0.005) \text { and controls }(p<0.001) \text {. Complete } \\
\text { tumor regression was seen in } 25 \% \text { of combination-treated mice } \\
\text { but no other subgroups. }\end{array}$ \\
\hline $\begin{array}{c}\text { Otani et al. [100] } \\
\text { (2021) }\end{array}$ & Glioblastoma & $\begin{array}{l}\text { LB100 and PRMT5 } \\
\text { knockdown }\end{array}$ & $\begin{array}{l}\text { LB100 administration significantly reduced viability in } \\
\text { PRMT5-depleted GBMNS compared to PRMT5-intact GBMNS. } \\
\text { PRMT5 knockdown and LB100 combination therapy increased } \\
\text { the expression of phospho-MLKL. Combination therapy } \\
\text { significantly decreased tumor size and prolonged survival in } \\
\text { in vivo mouse xenografts. }\end{array}$ \\
\hline Lu et al. [94] (2009) & $\begin{array}{l}\text { Neuroblastoma } \\
\text { and GBM }\end{array}$ & LB102 and TMZ & $\begin{array}{c}\text { LB102 treatment in U87MG GBM cells resulted in morphological } \\
\text { features of mitotic catastrophe. LB102 caused complete regression } \\
\text { of GBM xenografts with no recurrence in } 50 \% \text { of animals and } \\
\text { inhibited the growth of NB xenografts. }\end{array}$ \\
\hline $\begin{array}{c}\text { Martiniova et al. } \\
\text { [101] (2011) }\end{array}$ & Pheochromocytoma & LB100 and TMZ & $\begin{array}{l}\text { Combination therapy resulted in significantly greater tumor cell } \\
\text { inhibition in vitro compared to monotherapy. PHEO mouse } \\
\text { xenografts treated with combination therapy had significantly } \\
\text { prolonged survival compared to monotherapy }(p<0.0001) \text {. } \\
\text { Combination therapy significantly delayed the appearance of } \\
\text { hepatic tumors compared to monotherapy alone }(p<0.0001) \text {. }\end{array}$ \\
\hline Ho et al. [87] (2016) & Medulloblastoma & $\begin{array}{l}\text { LB100 and } \\
\text { cisplatin }\end{array}$ & $\begin{array}{l}\text { LB100 alone had a potent antitumor effect of multiple } \\
\text { medulloblastoma cell lines. Combination therapy enhanced } \\
\text { cisplatin cytotoxicity and significantly decreased } \\
\text { medulloblastoma cell viability as compared to controls }(p<0.005) \text {. } \\
\text { Combination therapy significantly reduced tumor burden on } \\
\text { POD64 compared to cisplatin treatment alone }(p<0.05) \text { in vivo. }\end{array}$ \\
\hline $\begin{array}{l}\text { Schramm et al. } \\
\text { [110] (2019) }\end{array}$ & DIPG & LB100 only & $\begin{array}{l}\text { Investigators used a large-scale gene knockdown approach using } \\
\text { shRNA and DNA sequencing to identify susceptibilities of DIPG } \\
\text { tumor cells. Screening resulted in FGFR and PP2A deemed as } \\
\text { candidate targets. LB100 therapy induced apoptosis in two DIPG } \\
\text { cell lines in a dose-dependent manner and increased pAkt } \\
\text { expression in vitro. }\end{array}$ \\
\hline
\end{tabular}

\subsection{Neuroblastoma}

Neuroblastoma has variable clinical behavior, in which some tumors spontaneously regress while others progress even with aggressive therapy regimens. Despite advances in multimodal therapy, achieving therapeutic success in neuroblastoma is often a challenge. Surgery and chemotherapy are usually used initially and may be curative. The prognosis for 
children with high-risk neuroblastoma variants is poor, necessitating innovative treatment options. In patients unresponsive to standard measures, novel agents may be employed, most of which target the MYCN oncogene and proangiogenetic factors [111]. Lu et al. studied the antitumor effects of PP2A inhibitor LB102 (lipid-soluble homolog of LB100) in combination with temozolomide (TMZ) in neuroblastoma (NB) and GBM mouse xenograft models (Table 2) [94]. The investigators found that PP2A inhibition increased the antitumor activity of TMZ and completely suppressed tumor growth in mice implanted with NB xenografts. This study demonstrated the chemosensitizing properties of LB100 when given with TMZ, an alkylating chemotherapeutic agent.

\section{Biological Insights and Future Directions}

LB100 use as an adjuvant chemotherapeutic agent has advanced from preclinical in vitro and in vivo experiments to clinical trials. One phase I clinical trial of LB100 in the treatment of solid tumors has been completed (ClinicalTrials.gov Identifier: NCT01837667) and achieved promising results [112]. This study, conducted by Chung et al., was an open-label, dose-escalation phase I trial where 29 study participants with progressive solid tumors received intravenous doses of LB100 daily for 3 days, administered in 21day cycles [112]. Ten of the twenty patients who were available to respond achieved stable disease for four or more cycles. Two patients had dose-limiting toxicity, and one patient who initially stopped treatment due to an acute infection was later reenrolled. The objective of this initial trial was to determine the maximum tolerated dose of LB100 while also evaluating its safety and activity. Interestingly, LB100 was administered to trial subjects as a monotherapy. Currently, evidence has indicated that LB100 exerts its antitumor effects primarily through chemo- and radiosensitization [10]. This idea was supported by the aforementioned study conducted by Lu et al. who showed the chemosensitizing effects of an LB100 analog on neuroblastoma and GBM cells [94]. Treatment with LB-1.2 was associated with increased phosphorylation of MDM2 and decreased phosphorylated p53.

MDM2 functions to inhibit the tumor suppressor activity of p53 [113]. However, reports have revealed that MDM2 may, in fact, positively regulate p53 under certain conditions, such as after ATM-dependent MDM2 phosphorylation which enhances p53 translation. This is particularly relevant to GBM tumor biology given that the p53-ARFMDM2 pathway is reported to be deregulated in $84 \%$ of patients with GBM [113]. The rescue of this pathway via LB100-induced phosphorylation of MDM2, with subsequent upregulation of tumor suppressor p53, highlights a potential antitumor mechanism that likely warrants further study and clinical translation.

Since the initial clinical trial by Chung et al., another trial evaluating the efficacy of LB100 in the treatment of recurrent GBM is ongoing and still recruiting patients (ClinicalTrials.gov Identifier: NCT03027388). This is a two-stage, phase II, open-label trial which aims to delineate the pharmacodynamics and pharmacokinetics of LB100 monotherapy in patients with recurrent high-grade gliomas. Furthermore, this study will serve to determine whether LB100 can cross the blood-brain barrier (BBB) in humans and at what plasma concentrations LB100 can penetrate the BBB at an effective therapeutic dose. With the proper characterization of the BBB penetration profile of LB100, treatment can be clinically optimized for its administration with additional chemotherapeutic agents. While progress has been made in evaluating its anticancer properties in early phase clinical trials, a significant research gap exists concerning the possible role that LB100 could play in improving the treatment of solid nervous system tumors.

\section{Conclusions}

GBM and most other CNS gliomas defy cure because of their unique tumor biology and invasion into anatomical regions of eloquent neurological function. Better treatment of these tumors is needed and will result from advancements in neuro-oncologic research identifying tumor susceptibilities that may be targeted with new therapeutic agents, such 
as LB100 and other PP2A inhibitors. Further investigations will elucidate the efficacy of this drug in reducing the disease burden of peripheral and central nervous system neoplasms.

Author Contributions: Conception: Y.K.B.-S.; Writing original draft: J.-P.B. and A.L.; Editing of the manuscript: J.-P.B., J.H., and Y.K.B.-S. All authors have read and agreed to the published version of the manuscript.

Funding: Supported by Intramural Research Program at the National Institute of Neurological Disorders and Stroke at the NIH.

Declaration of Interest: Not applicable.

Institutional Review Board Statement: Not applicable.

Data Availability Statement: Not applicable.

Acknowledgments: This research was made possible through the NIH Medical Research Scholars Program, a public-private partnership supported jointly by the NIH and contributions to the Foundation for the NIH from the Doris Duke Charitable Foundation, Genentech, the American Association for Dental Research, and the Colgate-Palmolive Company.

Conflicts of Interest: The authors declare no conflict of interest.

\section{References}

1. Perrotti, D.; Neviani, P. Protein phosphatase 2A: A target for anticancer therapy. Lancet Oncol. 2013, 14, e229-e238. [CrossRef]

2. Leslie, S.; Nairn, A.C. cAMP regulation of protein phosphatases PP1 and PP2A in brain. Biochim. Biophys. Acta Bioenerg. 2019, 1866, 64-73. [CrossRef] [PubMed]

3. Wlodarchak, N.; Xing, Y. PP2A as a master regulator of the cell cycle. Crit. Rev. Biochem. Mol. Biol. 2016, 51, 162-184. [CrossRef] [PubMed]

4. Park, H.; Lee, K.; Park, E.S.; Oh, S.; Yan, R.; Zhang, J.; Beach, T.G.; Adler, C.H.; Voronkov, M.; Braithwaite, S.P.; et al. Dysregulation of protein phosphatase 2A in parkinson disease and dementia with lewy bodies. Ann. Clin. Transl. Neurol. 2016, 3, 769-780. [CrossRef]

5. Gong, C.-X.; Singh, T.J.; Grundke-Iqbal, I.; Iqbal, K. Phosphoprotein Phosphatase Activities in Alzheimer Disease Brain. J. Neurochem. 1993, 61, 921-927. [CrossRef] [PubMed]

6. Sontag, E.; Luangpirom, A.; Hladik, C.; Mudrak, I.; Ogris, E.; Speciale, S.; White, C.L., III. Altered Expression Levels of the Protein Phosphatase 2A AB $\alpha$ C Enzyme Are Associated with Alzheimer Disease Pathology. J. Neuropathol. Exp. Neurol. 2004, 63, $287-301$. [CrossRef]

7. Javadpour, P.; Dargahi, L.; Ahmadiani, A.; Ghasemi, R. To be or not to be: PP2A as a dual player in CNS functions, its role in neurodegeneration, and its interaction with brain insulin signaling. Cell. Mol. Life Sci. 2019, 76, 2277-2297. [CrossRef] [PubMed]

8. Narla, G.; Sangodkar, J.; Ryder, C.B. The impact of phosphatases on proliferative and survival signaling in cancer. Cell. Mol. Life Sci. 2018, 75, 2695-2718. [CrossRef]

9. Meeusen, B.; Janssens, V. Tumor suppressive protein phosphatases in human cancer: Emerging targets for therapeutic intervention and tumor stratification. Int. J. Biochem. Cell Biol. 2018, 96, 98-134. [CrossRef] [PubMed]

10. Hong, C.S.; Ho, W.; Zhang, C.; Yang, C.; Elder, J.B.; Zhuang, Z. LB100, a small molecule inhibitor of PP2A with potent chemo- and radio-sensitizing potential. Cancer Biol. Ther. 2015, 16, 821-833. [CrossRef]

11. Laplante, M.; Sabatini, D.M. mTOR Signaling in Growth Control and Disease. Cell 2012, 149, 274-293. [CrossRef] [PubMed]

12. Mossmann, D.; Park, S.; Hall, M.N. mTOR signalling and cellular metabolism are mutual determinants in cancer. Nat. Rev. Cancer 2018, 18, 744-757. [CrossRef] [PubMed]

13. Showkat, M.; Beigh, M.A.; Andrabi, K.I. mTOR Signaling in Protein Translation Regulation: Implications in Cancer Genesis and Therapeutic Interventions. Mol. Biol. Int. 2014, 2014, 686984. [CrossRef] [PubMed]

14. Murugan, A.K. mTOR: Role in cancer, metastasis and drug resistance. Semin. Cancer Biol. 2019, 59, 92-111. [CrossRef] [PubMed]

15. Nakamura, J.L.; Garcia, E.; Pieper, R.O. S6K1 Plays a Key Role in Glial Transformation. Cancer Res. 2008, 68, 6516-6523. [CrossRef]

16. Zhang, T.; Guo, J.; Li, H.; Wang, J. Meta-analysis of the prognostic value of p-4EBP1 in human malignancies. Oncotarget 2017, 9, 2761-2769. [CrossRef]

17. Peterson, R.T.; Desai, B.N.; Hardwick, J.S.; Schreiber, S.L. Protein phosphatase 2A interacts with the 70-kDa S6 kinase and is activated by inhibition of FKBP12-rapamycinassociated protein. Proc. Natl. Acad. Sci. USA 1999, 96, 4438-4442. [CrossRef] [PubMed]

18. Nakashima, A.; Tanimura-Ito, K.; Oshiro, N.; Eguchi, S.; Miyamoto, T.; Momonami, A.; Kamada, S.; Yonezawa, K.; Kikkawa, U. A positive role of mammalian Tip41-like protein, TIPRL, in the amino-acid dependent mTORC1-signaling pathway through interaction with PP2A. FEBS Lett. 2013, 587, 2924-2929. [CrossRef]

19. Pachow, D.; Wick, W.; Gutmann, D.H.; Mawrin, C. The mTOR signaling pathway as a treatment target for intracranial neoplasms. Neuro-Oncology 2014, 17, 189-199. [CrossRef] 
20. Plamper, M.; Born, M.; Gohlke, B.; Schreiner, F.; Schulte, S.; Splittstößer, V.; Woelfle, J.; Michaela, P.; Mark, B.; Bettina, G.; et al. Cerebral MRI and Clinical Findings in Children with PTEN Hamartoma Tumor Syndrome: Can Cerebral MRI Scan Help to Establish an Earlier Diagnosis of PHTS in Children? Cells 2020, 9, 1668. [CrossRef]

21. Mellinghoff, I.K.; Wang, M.Y.; Vivanco, I.; Haas-Kogan, D.A.; Zhu, S.; Dia, E.Q.; Lu, K.V.; Yoshimoto, K.; Huang, J.H.; Chute, D.J.; et al. Molecular Determinants of the Response of Glioblastomas to EGFR Kinase Inhibitors. N. Engl. J. Med. 2005, 353, 2012-2024. [CrossRef] [PubMed]

22. Masica, D.L.; Karchin, R. Correlation of Somatic Mutation and Expression Identifies Genes Important in Human Glioblastoma Progression and Survival. Cancer Res. 2011, 71, 4550-4561. [CrossRef]

23. Clevers, H. Wnt/ $\beta$-Catenin Signaling in Development and Disease. Cell 2006, 127, 469-480. [CrossRef] [PubMed]

24. Julius, M.; Schelbert, B.; Hsu, W.; Fitzpatrick, E.; Jho, E.-H.; Fagotto, F.; Costantini, F.; Kitajewski, J. Domains of Axin and Disheveled Required for Interaction and Function in Wnt Signaling. Biochem. Biophys. Res. Commun. 2000, 276, 1162-1169. [CrossRef]

25. Behrens, J.; Von Kries, J.P.; Kühl, M.; Bruhn, L.; Wedlich, D. Functional interaction of $\beta$-catenin with the transcription factor LEF-1. Nat. Cell Biol. 1996, 382, 638-642. [CrossRef] [PubMed]

26. Krishnamurthy, N.; Kurzrock, R. Targeting the Wnt/beta-catenin pathway in cancer: Update on effectors and inhibitors. Cancer Treat. Rev. 2018, 62, 50-60. [CrossRef]

27. Reya, T.; Clevers, H. Wnt signalling in stem cells and cancer. Nat. Cell Biol. 2005, 434, 843-850. [CrossRef]

28. Vermeulen, L.; Melo, F.D.S.E.; Van Der Heijden, M.; Cameron, K.; De Jong, J.H.; Borovski, T.; Tuynman, J.B.; Todaro, M.; Merz, C.; Rodermond, H.; et al. Wnt activity defines colon cancer stem cells and is regulated by the microenvironment. Nat. Cell Biol. 2010, 12, 468-476. [CrossRef]

29. Latres, E.; Chiaur, D.S.; Pagano, M. The human F box protein $\beta$-Trcp associates with the Cul1/Skp1 complex and regulates the stability of $\beta$-catenin. Oncogene 1999, 18, 849-854. [CrossRef]

30. Ha, N.-C.; Tonozuka, T.; Stamos, J.L.; Choi, H.-J.; Weis, W.I. Mechanism of Phosphorylation-Dependent Binding of APC to $\beta$-Catenin and Its Role in $\beta$-Catenin Degradation. Mol. Cell 2004, 15, 511-521. [CrossRef]

31. Jho, E.-H.; Lomvardas, S.; Costantini, F. A GSK3 $\beta$ Phosphorylation Site in Axin Modulates Interaction with $\beta$-Catenin and Tcf-Mediated Gene Expression. Biochem. Biophys. Res. Commun. 1999, 266, 28-35. [CrossRef]

32. Jiang, Y.; Luo, W.; Howe, P.H. Dab2 stabilizes Axin and attenuates Wnt/ $\beta$-catenin signaling by preventing protein phosphatase 1 (PP1)-Axin interactions. Oncogene 2009, 28, 2999-3007. [CrossRef]

33. Seshacharyulu, P.; Pandey, P.; Datta, K.; Batra, S.K. Phosphatase: PP2A structural importance, regulation and its aberrant expression in cancer. Cancer Lett. 2013, 335, 9-18. [CrossRef] [PubMed]

34. Zhang, W.; Yang, J.; Liu, Y.; Chen, X.; Yu, T.; Jia, J.; Liu, C. PR55 $\alpha$, a Regulatory Subunit of PP2A, Specifically Regulates PP2A-mediated $\beta$-Catenin Dephosphorylation. J. Biol. Chem. 2009, 284, 22649-22656. [CrossRef] [PubMed]

35. Hein, A.L.; Seshacharyulu, P.; Rachagani, S.; Sheinin, Y.M.; Ouellette, M.M.; Ponnusamy, M.P.; Mumby, M.C.; Batra, S.K.; Yan, Y. PR55 $\alpha$ Subunit of Protein Phosphatase 2A Supports the Tumorigenic and Metastatic Potential of Pancreatic Cancer Cells by Sustaining Hyperactive Oncogenic Signaling. Cancer Res. 2016, 76, 2243-2253. [CrossRef] [PubMed]

36. Yokoyama, N.; Malbon, C.C. Phosphoprotein phosphatase-2A docks to Dishevelled and counterregulates Wnt3a/ $\beta$-catenin signaling. J. Mol. Signal. 2007, 2, 12. [CrossRef] [PubMed]

37. Mitra, A.; Menezes, M.E.; Pannell, L.K.; Mulekar, M.S.; Honkanen, R.E.; Shevde, L.A.; Samant, R.S. DNAJB6 chaperones PP2A mediated dephosphorylation of GSK3 $\beta$ to downregulate $\beta$-catenin transcription target, osteopontin. Oncogene 2012, 31, $4472-4483$. [CrossRef] [PubMed]

38. Santiago, L.; Daniels, G.; Wang, D.; Deng, F.-M.; Lee, P. Wnt signaling pathway protein LEF1 in cancer, as a biomarker for prognosis and a target for treatment. Am. J. Cancer Res. 2017, 7, 1389-1406.

39. Arnés, M.; Tintó, S.C. Aberrant Wnt signaling: A special focus in CNS diseases. J. Neurogenet. 2017, 31, 216-222. [CrossRef]

40. Auger, N.; Thillet, J.; Wanherdrick, K.; Idbaih, A.; Legrier, M.-E.; Dutrillaux, B.; Sanson, M.; Poupon, M.-F. Genetic alterations associated with acquired temozolomide resistance in SNB-19, a human glioma cell line. Mol. Cancer Ther. 2006, 5, $2182-2192$. [CrossRef] [PubMed]

41. Jin, X.; Jeon, H.-Y.; Joo, K.M.; Kim, J.-K.; Jin, J.; Kim, S.H.; Kang, B.G.; Beck, S.; Lee, S.J.; Kim, J.K.; et al. Frizzled 4 Regulates Stemness and Invasiveness of Migrating Glioma Cells Established by Serial Intracranial Transplantation. Cancer Res. 2011, 71, 3066-3075. [CrossRef] [PubMed]

42. Dhillon, A.S.; Hagan, S.; Rath, O.; Kolch, W. MAP kinase signalling pathways in cancer. Oncogene 2007, 26, 3279-3290. [CrossRef] [PubMed]

43. Sun, Y.; Liu, W.-Z.; Liu, T.; Feng, X.; Yang, N.; Zhou, H.-F. Signaling pathway of MAPK/ERK in cell proliferation, differentiation, migration, senescence and apoptosis. J. Recept. Signal. Transduct. 2015, 35, 600-604. [CrossRef]

44. Guo, Y.; Pan, W.; Liu, S.; Shen, Z.; Xu, Y.; Hu, L. ERK/MAPK signalling pathway and tumorigenesis (Review). Exp. Ther. Med. 2020, 19, 1997-2007. [CrossRef]

45. Wang, C.X.; Xiong, H.F.; Wang, S.; Wang, J.; Nie, X.; Guo, Q.; Li, X.; Qi, Y.; Liu, J.J.; Lin, B. Overexpression of TEM8 promotes ovarian cancer progression via Rac1/Cdc42/JNK and MEK/ERK/STAT3 signaling pathways. Am. J. Transl. Res. 2020, 12, $3557-3576$. 
46. Ugi, S.; Imamura, T.; Ricketts, W.; Olefsky, J.M. Protein Phosphatase 2A Forms a Molecular Complex with Shc and Regulates Shc Tyrosine Phosphorylation and Downstream Mitogenic Signaling. Mol. Cell. Biol. 2002, 22, 2375-2387. [CrossRef] [PubMed]

47. Lao, D.-H.; Yusoff, P.; Chandramouli, S.; Philp, R.J.; Fong, C.W.; Jackson, R.A.; Saw, T.Y.; Yu, C.Y.; Guy, G.R. Direct Binding of PP2A to Sprouty2 and Phosphorylation Changes Are a Prerequisite for ERK Inhibition Downstream of Fibroblast Growth Factor Receptor Stimulation. J. Biol. Chem. 2007, 282, 9117-9126. [CrossRef]

48. Zwaenepoel, K.; Goris, J.; Erneux, C.; Parker, P.J.; Janssens, V. Protein phosphatase 2A PR130/B" $\alpha: 1$ subunit binds to the SH2 domain-containing inositol polyphosphate 5-phosphatase 2 and prevents epidermal growth factor (EGF)-induced EGF receptor degradation sustaining EGF-mediated signaling. FASEB J. 2009, 24, 538-547. [CrossRef] [PubMed]

49. Jaumot, M.; Hancock, J.F. Protein phosphatases 1 and 2A promote Raf-1 activation by regulating 14-3-3 interactions. Oncogene 2001, 20, 3949-3958. [CrossRef]

50. DeClue, J.E.; Papageorge, A.G.; Fletcher, J.A.; Diehl, S.R.; Ratner, N.; Vass, W.C.; Lowy, D.R. Abnormal regulation of mammalian p21ras contributes to malignant tumor growth in von Recklinghausen (type 1) neurofibromatosis. Cell 1992, 69, 265-273. [CrossRef]

51. Lewis, R.A.; Gerson, L.P.; Axelson, K.A.; Riccardi, V.M.; Whitford, R.P. von Recklinghausen Neurofibromatosis. Ophthalmology 1984, 91, 929-935. [CrossRef]

52. Daniel, P.M.; Filiz, G.; Tymms, M.J.; Ramsay, R.G.; Kaye, A.H.; Stylli, S.S.; Mantamadiotis, T. Intratumor MAPK and PI3K signaling pathway heterogeneity in glioblastoma tissue correlates with CREB signaling and distinct target gene signatures. Exp. Mol. Pathol. 2018, 105, 23-31. [CrossRef]

53. Skinner, M.; Ward, S.M.; Nilsson, C.L.; Emrick, T. Augmenting Glioblastoma Chemotherapy with Polymers. ACS Chem. Neurosci. 2017, 9, 8-10. [CrossRef]

54. Liu, B.; Sun, L.-H.; Huang, Y.-F.; Guo, L.-J.; Luo, L.-S. Protein phosphatase 2AC $\alpha$ gene knock-out results in cortical atrophy through activating hippo cascade in neuronal progenitor cells. Int. J. Biochem. Cell Biol. 2018, 95, 53-62. [CrossRef]

55. Yamashita, T.; Inui, S.; Maeda, K.; Hua, D.R.; Takagi, K.; Fukunaga, K.; Sakaguchi, N. Regulation of CaMKII by $\alpha 4 /$ PP2Ac contributes to learning and memory. Brain Res. 2006, 1082, 1-10. [CrossRef]

56. Rossetti, T.; Banerjee, S.; Kim, C.; Leubner, M.; Lamar, C.; Gupta, P.; Lee, B.; Neve, R.; Lisman, J. Memory Erasure Experiments Indicate a Critical Role of CaMKII in Memory Storage. Neuron 2017, 96, 207-216.e2. [CrossRef]

57. Monroe, J.D.; Heathcote, R.D. Protein phosphatases regulate the growth of developing neurites. Int. J. Dev. Neurosci. 2013, 31, 250-257. [CrossRef]

58. Miyamoto, Y.; Torii, T.; Yamamori, N.; Ogata, T.; Tanoue, A.; Yamauchi, J. Akt and PP2A Reciprocally Regulate the Guanine Nucleotide Exchange Factor Dock6 to Control Axon Growth of Sensory Neurons. Sci. Signal. 2013, 6, ra15. [CrossRef] [PubMed]

59. Zhu, L.-Q.; Zheng, H.-Y.; Peng, C.-X.; Liu, D.; Li, H.-L.; Wang, Q.; Wang, J.-Z. Protein Phosphatase 2A Facilitates Axonogenesis by Dephosphorylating CRMP2. J. Neurosci. 2010, 30, 3839-3848. [CrossRef] [PubMed]

60. Nematullah; Hoda, M.N.; Khan, F. Protein Phosphatase 2A: A Double-Faced Phosphatase of Cellular System and Its Role in Neurodegenerative Disorders. Mol. Neurobiol. 2017, 55, 1750-1761. [CrossRef] [PubMed]

61. Sim, A.T.; Lloyd, H.G.; Jarvie, P.E.; Morrison, M.; Rostas, J.A.; Dunkley, P.R. Synaptosomal amino acid release: Effect of inhibiting protein phosphatases with okadaic acid. Neurosci. Lett. 1993, 160, 181-184. [CrossRef]

62. Beaulieu, J.-M.; Sotnikova, T.D.; Marion, S.; Lefkowitz, R.J.; Gainetdinov, R.; Caron, M.G. An Akt/ $\beta$-Arrestin 2/PP2A Signaling Complex Mediates Dopaminergic Neurotransmission and Behavior. Cell 2005, 122, 261-273. [CrossRef]

63. Avila, J.; Lucas, J.J.; Pérez, M.; Hernandez, F. Role of Tau Protein in Both Physiological and Pathological Conditions. Physiol. Rev. 2004, 84, 361-384. [CrossRef]

64. Kimura, T.; Sharma, G.; Ishiguro, K.; Hisanaga, S.-I. Phospho-Tau Bar Code: Analysis of Phosphoisotypes of Tau and Its Application to Tauopathy. Front. Neurosci. 2018, 12, 44. [CrossRef]

65. Liu, F.; Grundke-Iqbal, I.; Iqbal, K.; Gong, C.-X. Contributions of protein phosphatases PP1, PP2A, PP2B and PP5 to the regulation of tau phosphorylation. Eur. J. Neurosci. 2005, 22, 1942-1950. [CrossRef] [PubMed]

66. Sontag, E.; Nunbhakdi-Craig, V.; Lee, G.; Bloom, G.S.; Mumby, M.C. Regulation of the Phosphorylation State and MicrotubuleBinding Activity of Tau by Protein Phosphatase 2A. Neuron 1996, 17, 1201-1207. [CrossRef]

67. Schild, A.; Ittner, L.M.; Götz, J. Altered phosphorylation of cytoskeletal proteins in mutant protein phosphatase 2A transgenic mice. Biochem. Biophys. Res. Commun. 2006, 343, 1171-1178. [CrossRef] [PubMed]

68. Hoffman, A.; Taleski, G.; Sontag, E. The protein serine/threonine phosphatases PP2A, PP1 and calcineurin: A triple threat in the regulation of the neuronal cytoskeleton. Mol. Cell. Neurosci. 2017, 84, 119-131. [CrossRef] [PubMed]

69. Park, H.-J.; Lee, K.-W.; Oh, S.; Yan, R.; Zhang, J.; Beach, T.G.; Adler, C.H.; Voronkov, M.; Braithwaite, S.P.; Stock, J.B.; et al. Protein Phosphatase 2A and Its Methylation Modulating Enzymes LCMT-1 and PME-1 Are Dysregulated in Tauopathies of Progressive Supranuclear Palsy and Alzheimer Disease. J. Neuropathol. Exp. Neurol. 2018, 77, 139-148. [CrossRef] [PubMed]

70. Arif, M.; Kazim, S.F.; Grundke-Iqbal, I.; Garruto, R.M.; Iqbal, K. Tau pathology involves protein phosphatase 2A in Parkinsonismdementia of Guam. Proc. Natl. Acad. Sci. USA 2014, 111, 1144. [CrossRef] [PubMed]

71. Sontag, J.-M.; Sontag, E. Protein phosphatase 2A dysfunction in Alzheimer's disease. Front. Mol. Neurosci. 2014, 7, 16. [CrossRef]

72. Chen, W.; Arroyo, J.D.; Timmons, J.C.; Possemato, R.; Hahn, W.C. Cancer-Associated PP2A A $\alpha$ Subunits Induce Functional Haploinsufficiency and Tumorigenicity. Cancer Res. 2005, 65, 8183-8192. [CrossRef] 
73. Cheng, Y.C.; Liu, W.; Kim, S.-T.; Sun, J.; Lu, L.; Sun, J.; Zheng, S.L.; Isaacs, W.B.; Xu, J. Evaluation of PPP2R2A as a prostate cancer susceptibility gene: A comprehensive germline and somatic study. Cancer Genet. 2011, 204, 375-381. [CrossRef] [PubMed]

74. Haesen, D.; Asbagh, L.A.; Derua, R.; Hubert, A.; Schrauwen, S.; Hoorne, Y.; Amant, F.; Waelkens, E.; Sablina, A.; Janssens, V. Recurrent PPP2R1A Mutations in Uterine Cancer Act through a Dominant-Negative Mechanism to Promote Malignant Cell Growth. Cancer Res. 2016, 76, 5719-5731. [CrossRef]

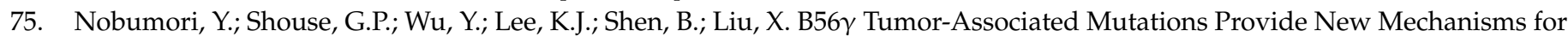
B56 $\gamma$-PP2A Tumor Suppressor Activity. Mol. Cancer Res. 2013, 11, 995-1003. [CrossRef]

76. Saddoughi, S.A.; Gencer, S.; Peterson, Y.K.; Ward, K.E.; Mukhopadhyay, A.; Oaks, J.; Bielawski, J.; Szulc, Z.M.; Thomas, R.J.; Selvam, S.P.; et al. Sphingosine analogue drug FTY720 targets I2PP2A/SET and mediates lung tumour suppression via activation of PP2A-RIPK1-dependent necroptosis. EMBO Mol. Med. 2012, 5, 105-121. [CrossRef]

77. Shouse, G.; De Necochea-Campion, R.; Mirshahidi, S.; Liu, X.; Chen, C.-S. Novel B55 $\alpha$-PP2A mutations in AML promote AKT T308 phosphorylation and sensitivity to AKT inhibitor-induced growth arrest. Oncotarget 2016, 7, 61081-61092. [CrossRef] [PubMed]

78. Grech, G.; Baldacchino, S.; Saliba, C.; Grixti, M.P.; Gauci, R.; Petroni, V.; Fenech, A.G.; Scerri, C. Deregulation of the protein phosphatase 2A, PP2A in cancer: Complexity and therapeutic options. Tumor Biol. 2016, 37, 11691-11700. [CrossRef] [PubMed]

79. Janssens, V.; Zwaenepoel, K.; Rossé, C.; Petit, M.M.R.; Goris, J.; Parker, P.J. PP2A binds the LIM-domains of Lipoma Preferred Partner via its PR130/B" subunit to regulate cell adhesion and migration. J. Cell Sci. 2016, 129, 1605-1618. [CrossRef] [PubMed]

80. Tang, Y.; Fang, G.; Guo, F.; Zhang, H.; Chen, X.; An, L.; Chen, M.; Zhou, L.; Wang, W.; Ye, T.; et al. Selective Inhibition of STRN3-Containing PP2A Phosphatase Restores Hippo Tumor-Suppressor Activity in Gastric Cancer. Cancer Cell 2020, 38, 115-128.e9. [CrossRef]

81. Zhao, B.; Li, L.; Tumaneng, K.; Wang, C.-Y.; Guan, K.-L. A coordinated phosphorylation by Lats and CK1 regulates YAP stability through SCF -TRCP. Genes Dev. 2010, 24, 72-85. [CrossRef]

82. Wu, S.; Liu, Y.; Zheng, Y.; Dong, J.; Pan, D. The TEAD/TEF Family Protein Scalloped Mediates Transcriptional Output of the Hippo Growth-Regulatory Pathway. Dev. Cell 2008, 14, 388-398. [CrossRef] [PubMed]

83. Kalev, P.; Simicek, M.; Vazquez, I.; Munck, S.; Chen, L.; Soin, T.; Danda, N.; Chen, W.; Sablina, A. Loss of PPP2R2A Inhibits Homologous Recombination DNA Repair and Predicts Tumor Sensitivity to PARP Inhibition. Cancer Res. 2012, 72, 6414-6424. [CrossRef] [PubMed]

84. Wei, D.; Parsels, L.A.; Karnak, D.; Davis, M.A.; Parsels, J.D.; Marsh, A.C.; Zhao, L.; Maybaum, J.; Lawrence, T.S.; Sun, Y.; et al. Inhibition of Protein Phosphatase 2A Radiosensitizes Pancreatic Cancers by Modulating CDC25C/CDK1 and Homologous Recombination Repair. Clin. Cancer Res. 2013, 19, 4422-4432. [CrossRef] [PubMed]

85. Mazhar, S.; Taylor, S.E.; Sangodkar, J.; Narla, G. Targeting PP2A in cancer: Combination therapies. Biochim. Biophys. Acta Mol. Cell Res. 2019, 1866, 51-63. [CrossRef] [PubMed]

86. Qiu, P.; Wang, S.; Liu, M.; Ma, H.; Zeng, X.; Zhang, M.; Xu, L.; Cui, Y.; Xu, H.; Tang, Y.; et al. Norcantharidin Inhibits cell growth by suppressing the expression and phosphorylation of both EGFR and c-Met in human colon cancer cells. BMC Cancer 2017, 17, 1-7. [CrossRef]

87. Ho, W.S.; Feldman, M.J.; Maric, D.; Amable, L.; Hall, M.D.; Feldman, G.M.; Ray-Chaudhury, A.; Lizak, M.J.; Vera, J.-C.; Robison, R.A.; et al. PP2A inhibition with LB100 enhances cisplatin cytotoxicity and overcomes cisplatin resistance in medulloblastoma cells. Oncotarget 2016, 7, 12447-12463. [CrossRef]

88. Swingle, M.; Ni, L.; Honkanen, R.E. Small-molecule inhibitors of ser/thr protein phosphatases: Specificity, use and common forms of abuse. Breast Cancer 2007, 365, 23-38. [CrossRef]

89. Honkanen, R.; Golden, T. Regulators of Serine / Threonine Protein Phosphatases at the Dawn of a Clinical Era? Curr. Med. Chem. 2002, 9, 2055-2075. [CrossRef]

90. Han, K.; Gan, Z.; Lin, S.; Hu, H.; Shen, Z.; Min, D. Elevated expression of serine/threonine phosphatase type 5 correlates with malignant proliferation in human osteosarcoma. Acta Biochim. Pol. 2017, 64, 11-16. [CrossRef]

91. Zhi, X.; Zhang, H.; He, C.; Wei, Y.; Bian, L.; Li, G. Serine/Threonine Protein Phosphatase-5 Accelerates Cell Growth and Migration in Human Glioma. Cell. Mol. Neurobiol. 2015, 35, 669-677. [CrossRef]

92. Golden, T.; Aragon, I.V.; Zhou, G.; Cooper, S.R.; Dean, N.M.; Honkanen, R.E. Constitutive over expression of serine/threonine protein phosphatase 5 (PP5) augments estrogen-dependent tumor growth in mice. Cancer Lett. 2004, 215, 95-100. [CrossRef]

93. D'Arcy, B.M.; Swingle, M.R.; Papke, C.M.; Abney, K.A.; Bouska, E.S.; Prakash, A.; Honkanen, R.E. The Antitumor Drug LB-100 Is a Catalytic Inhibitor of Protein Phosphatase 2A (PPP2CA) and 5 (PPP5C) Coordinating with the Active-Site Catalytic Metals in PPP5C. Mol. Cancer Ther. 2019, 18, 556-566. [CrossRef]

94. Lu, J.; Kovach, J.S.; Johnson, F.; Chiang, J.; Hodes, R.; Lonser, R.; Zhuang, Z. Inhibition of serine/threonine phosphatase PP2A enhances cancer chemotherapy by blocking DNA damage induced defense mechanisms. Proc. Natl. Acad. Sci. USA 2009, 106, 11697-11702. [CrossRef]

95. Lu, J.; Zhuang, Z.; Song, D.K.; Mehta, G.; Ikejiri, B.; Mushlin, H.; Park, D.M.; Lonser, R.R. The effect of a PP2A inhibitor on the nuclear receptor corepressor pathway in glioma. J. Neurosurg. 2010, 113, 225-233. [CrossRef]

96. Park, D.; Li, J.; Okamoto, H.; Akeju, O.; Kim, S.; Lubensky, I. N-CoR pathway targeting induces glioblastoma derived cancer stem cell differentiation. Cell Cycle 2007, 6, 467-470. [CrossRef] 
97. Gordon, I.K.; Lu, J.; Graves, C.A.; Huntoon, K.; Frerich, J.M.; Hanson, R.H.; Wang, X.; Hong, C.S.; Ho, W.; Feldman, M.J.; et al. Protein Phosphatase 2A Inhibition with LB100 Enhances Radiation-Induced Mitotic Catastrophe and Tumor Growth Delay in Glioblastoma. Mol. Cancer Ther. 2015, 14, 1540-1547. [CrossRef] [PubMed]

98. Cui, J.; Wang, H.; Medina, R.; Zhang, Q.; Xu, C.; Indig, I.H.; Zhou, J.; Song, Q.; Dmitriev, P.; Sun, M.Y.; et al. Inhibition of PP2A with LB-100 Enhances Efficacy of CAR-T Cell Therapy Against Glioblastoma. Cancers 2020, 12, 139. [CrossRef]

99. Maggio, D.; Ho, W.S.; Breese, R.; Walbridge, S.; Wang, H.; Cui, J.; Heiss, J.D.; Gilbert, M.R.; Kovach, J.S.; Lu, R.O.; et al. Inhibition of protein phosphatase-2A with LB-100 enhances antitumor immunity against glioblastoma. J. Neuro-Oncol. 2020, 148, 231-244. [CrossRef] [PubMed]

100. Otani, Y.; Sur, H.; Rachaiah, G.; Namagiri, S.; Chowdhury, A.; Lewis, C.T.; Shimizu, T.; Gangaplara, A.; Wang, X.; Vézina, A.; et al. Inhibiting protein phosphatase 2A increases the antitumor effect of protein arginine methyltransferase 5 inhibition in models of glioblastoma. Neuro-Oncology 2021. [CrossRef] [PubMed]

101. Martiniova, L.; Lu, J.; Chiang, J.; Bernardo, M.; Lonser, R.; Zhuang, Z.; Pacak, K. Pharmacologic Modulation of Serine/Threonine Phosphorylation Highly Sensitizes PHEO in a MPC Cell and Mouse Model to Conventional Chemotherapy. PLoS ONE 2011, 6, e14678. [CrossRef] [PubMed]

102. Corssmit, E.P.; Snel, M.; Kapiteijn, E. Malignant pheochromocytoma and paraganglioma: Management options. Curr. Opin. Oncol. 2020, 32, 20-26. [CrossRef]

103. Stupp, R.; Mason, W.P.; van den Bent, M.J.; Weller, M.; Fisher, B.; Taphoorn, M.J.B.; Belanger, K.; Brandes, A.A.; Marosi, C.; Bogdahn, U.; et al. Radiotherapy plus Concomitant and Adjuvant Temozolomide for Glioblastoma. N. Engl. J. Med. 2005, 352, 987-996. [CrossRef] [PubMed]

104. Menyhárt, O.; Győrffy, B. Molecular stratifications, biomarker candidates and new therapeutic options in current medulloblastoma treatment approaches. Cancer Metastasis Rev. 2020, 39, 211-233. [CrossRef] [PubMed]

105. Juraschka, K.; Taylor, M.D. Medulloblastoma in the age of molecular subgroups: A review. J. Neurosurg. Pediatr. 2019, 24, 353-363. [CrossRef] [PubMed]

106. Packer, R.J.; Zhou, T.; Holmes, E.; Vezina, G.; Gajjar, A. Survival and secondary tumors in children with medulloblastoma receiving radiotherapy and adjuvant chemotherapy: Results of Children's Oncology Group trial A9961. Neuro-Oncology 2013, 15, 97-103. [CrossRef] [PubMed]

107. Łastowska, M.; Trubicka, J.; Niemira, M.; Paczkowska-Abdulsalam, M.; Karkucińska-Więckowska, A.; Kaleta, M.; Drogosiewicz, M.; Perek-Polnik, M.; Kretowski, A.; Cukrowska, B.; et al. Medulloblastoma with transitional features between Group 3 and Group 4 is associated with good prognosis. J. Neuro-Oncol. 2018, 138, 231-240. [CrossRef]

108. Dasari, S.; Tchounwou, P.B. Cisplatin in cancer therapy: Molecular mechanisms of action. Eur. J. Pharmacol. 2014, 740, 364-378. [CrossRef]

109. Vanan, M.I.; Eisenstat, D.D. DIPG in Children-What Can We Learn from the Past? Front. Oncol. 2015, 5, 237. [CrossRef]

110. Schramm, K.; Iskar, M.; Statz, B.; Jäger, N.; Haag, D.; Słabicki, M.; Pfister, S.M.; Zapatka, M.; Gronych, J.; Jones, D.T.W.; et al. DECIPHER pooled shRNA library screen identifies PP2A and FGFR signaling as potential therapeutic targets for diffuse intrinsic pontine gliomas. Neuro-Oncology 2019, 21, 867-877. [CrossRef]

111. Ishola, T.A.; Chung, D.H. Neuroblastoma. Surg. Oncol. 2007, 16, 149-156. [CrossRef] [PubMed]

112. Chung, V.; Mansfield, A.S.; Braiteh, F.; Richards, D.; Durivage, H.; Ungerleider, R.S.; Johnson, F.; Kovach, J.S. Safety, Tolerability, and Preliminary Activity of LB-100, an Inhibitor of Protein Phosphatase 2A, in Patients with Relapsed Solid Tumors: An Open-Label, Dose Escalation, First-in-Human, Phase I Trial. Clin. Cancer Res. 2016, 23, 3277-3284. [CrossRef] [PubMed]

113. Zhang, Y.; Dube, C.; Gibert, J.M., Jr.; Cruickshanks, N.; Wang, B.; Coughlan, M.; Yang, Y.; Setiady, I.; Deveau, C.; Saoud, K.; et al. The p53 Pathway in Glioblastoma. Cancers 2018, 10, 297. [CrossRef] [PubMed] 